\title{
Ribes: A View from the Other Side
}

Ed M ashburn

\begin{abstract}
Additional IndeX words. currants, gooseberries, white pine blister rust, $\mathrm{Cronarti}$ um ribicola, $\mathrm{R}$ ibes nigrum, $\mathrm{R}$ ibes rubrum, R ibes uva-crispa.

Summary. In N orth A merica for many years the commonly held solution to white pine blister rust (Cronarti um ribicola J.C. Fischer) (WPBR) was to eradicate all currants and gooseberries (R ibes L.). That approach was tried to no avail. $C$ an currants and gooseberries be successfully grown in N orth America? You bet they can! Vast areas of the $U$ nited States and $C$ anada are ideal for $R$ ibes production. B lack currants (R ibesnigrum $L$.) are a processed fruit and production may compare to that of grain. $M$ any of the areas that presently grow other berries could easily grow $\mathrm{R}$ ibes The main barriers for production in $\mathrm{N}$ orth A merica are state restrictions and the availability of up-to-date information and data for growers, processors, legislators and the consuming public. I suggest that this conference and the people herein form that task group and initiate the cooperative dialogue and set forth a process to approach the WPBR problem in a holistic manner.
\end{abstract}

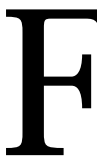

or most of the past century the commonly held solution to WPBR was to eradicate all $\mathrm{R}$ ibes $T$ hat approach was tried to no avail. The world production of currants and gooseberries in 1998 was a little more than $750,000 \mathrm{t}$ $(826,720$ ton). Germany, Poland and the Russian Federation produce a little more than 600,000 t (661,376 ton) or about $80 \%$ of this (Food and Agriculture O rganization of the $U$ nited $N$ ations, 1999). N orth America did not even show up on the list. Can currants and gooseberries be successfully grown in N orth America? You bet they can! Vast areas of the $U$ nited States and $C$ anada are ideal for R ibes production. Black currant production should not be compared to strawberry (Fragaria $x$ ananassa $D$ uschesne) or raspberry (R ubusidaeus $L$.) production, which are much more labor intensive. Black currants are a processed fruit and may compare more closely to grain production than to that of most berries. $\mathrm{R}$ ibes can be machine harvested; they don't have to planted each year; they come into production in a relatively short time; they require a minimal amount of input after the initial planting. Judging from what I have seen in this country, I believe that American plantings will have a higher per acre production than those in Europe. $M$ any of the areas that presently grow berries are within the ideal growing locations and processors could easily expand the $\mathrm{R}$ ibes fresh fruit market. The potential for a market in N orth America is enormous. Black currant juice has an intense pleasant flavor and color, and is high in ascorbic acid and several other nutrients. C onsumers are buying more healthful and unusual fruit and foods, and the black currant is considered a very healthful fruit.

\footnotetext{
Past president, The International Ribes Association. 707 Front St. Northumberland, PA 17857; e-mail ed@currants.com.

The cost of publishing this paper was defrayed in part by the payment of page charges. U nder postal regulations, this paper therefore must be hereby marked advertisement solely to indicate this fact.
} 
Black currant is a very useful product that may have a myriad of purported curative and preventative properties. It is said to cure warts, freckles, colds, rashes, sore throats, runny noses, urinaryproblems, heart trouble, high blood pressure, hangovers, cancer and makes child birth a pleasure. I won't vouch for these claims, but it is a replacement for all medicines and snake oil. Seriously, there are many references to the nutraceutical values of this plant and this really needs to have a thorough scientific evaluation. Black currants and their seeds contain significant levels of omega-6 PU FA, gamma-linolenic acid $(G L A)$ and other antioxidants that are very beneficial to health. This nutraceutical aspect will only be examined by having an amplesupply of $\mathrm{N}$ orth American fruit. Scandinavians and eastern Europeans are well aware of these values.

\section{Barriers to Ribes production}

The main barrier that needs to be addressed is the legislation against $R$ ibesthat is in placein manystatesand jurisdictions. U p-to-dateinformation concerning $\mathrm{R}$ ibes production is not available for legislators, growers, processors, or the consuming public. There is an urgent need to explore, define and disseminate factual information and recommendations in order that realistic decisionscan bemade. This conference is the beginning of an effort to address these issues. 0 fficials charged with the responsibility of pro- tecting our natural resources must have adequate data to make decisions. When the original restrictions were imposed no WPBR-resistant $R$ ibes were available. Times have changed. N ow several very good black currant cultivars are either WPBR immune or resistant. Pineshaveal so been selected for WPBR resistance. Some of the states are reviewing their legislated restrictions. This is a lengthy, costly, and difficult task. Some states just want to keep the present statute. The time has come to deliberate on these restrictions according to new information. A decision to do nothing maintains the status quo.

\section{The plan: What to do next}

Everyonehasafair share of responsibilitiesin thismatter. The horticulturists, growers and the fruit industry must seek, find, evaluate and authenticate the validity of useful selections that are, in fact, resistant. There must be a concerted effort to breed and select cultivars that do no harm, yet are useful to the industry.

Theforestersand thosein thebusiness of growing pines (PinusL.) need to seek and utilize resistant selections and to use cultural practices that minimize or break the cycle. This may include removing infected trees.

Conservationists, protectors, and legislators must seek factual reliable information and data to use in making decisions that will minimize the impact on both industries and yet provide reasonable protection to all concerned.

\section{The task and the task force}

A task group should be formed to facilitatethecollection, evaluation and dissemination of information and data. This multidisciplinary group could coordinate research efforts and make recommendations to interested parties. This group should have access to data from any source generating factual, pertinent findings. A World Wide Web site is available to post and to seek information (M cK ay, 1998). D o legislators use this site? This group could become a clearinghouse of information. This assemblage could be made up of people that are interested in the overall problem of WPBR. I suggest that a subcommittee from this conference and the people herein form that task group and initiate the cooperative dialogue and set forth a process to approach the WPBR problem in a holistic manner.

\section{Literature cited}

Food and Agriculture $O$ rganization of the U nited $\mathrm{N}$ ations. 1999. Food and Agricultural O rganization statistical database on agricultural production. 10 Sept. 1999. $<$ http:// apps.fao.org/lim500/ nphwrap.pl?Production.C rops $>$.

M cKay, S. 1998. White pine blister rust information page. Cornell Cooperative Extension of Columbia C ounty. 15 Sept. 1998. <http:/ / www.cce.cornell.edu/ columbia/ smckay/ wpbr.html>. 